\title{
PLANT DISCOVERIES IN SASKATCHEWAN, 1988-92, FEATURING SERPENT SPURGE AND FLUFFWEED
}

JOHN H. HUDSON, 103 Richmond Crescent, Saskatoon, Saskatchewan. S7K 1 A9

The last time I had an article in the Blue Jay about plant discoveries by me in Saskatchewan was in 1988, reporting on Foxtail Muhly (Muhlenbergia andina) having been found at Emma Lake, and a new record for the province. ${ }^{11}$ In the four years following years, I have found two plants new to Saskatchewan this comes to 0.5 novelty per year. This is a drop from the 1970s when I averaged 1.7 plants new to Saskatchewan per year - the law of diminishing returns is seen in action.

New to Saskatchewan is Euphorbia serpens H.B.K., which Booth and Wright call Serpent Spurge. ${ }^{4}$ This small annual, flat on the ground, looks just like the common weedy annual spurges of gardens, dry roadsides, and railroad embankments, except that the small $(4-5 \mathrm{~mm}$ diameter) leaves are almost round, rather than elliptical or oblong. Collection data are: \#5028, Lemsford Ferry, 15 August 1991, on steep bare butte of proglacial silts, L.S.D. 5 in 2-24-23 W. 3rd; \#5097, Lancer Ferry, 3 September 1992, dry bare eroded slope of clay till, south facing, L.S.D. 2 in 21-23-21 W. 3 rd.

Here we have two findings of a plant on the buttes along the South Saskatchewan River, and there is no reason why it should not be found elsewhere in the stretch between Empress and Lancer Ferry. In this stretch the river breaks consist of buttes seemingly composed mainly of stone-free and unfossiferous buff silt, with the occasional layer interbedded of stone-bearing and rather clayeyer till, (such as that from which \#5097 came) - all clearly Pleistocene in age. The geologic substrate of a rare plant is worth some inquiry. I had the feeling that I had read or heard somewhere that these thick silts were proglacial silts that had been deposited in lakes in front of the advancing continental glacier, but could find no reference which said just that.

What I did find was the report of P.P. David, a study of the glacial geology of the Prelate map sheet $72 \mathrm{~K}$, which includes Lancer Ferry. ${ }^{5}$ In the discussion of sections along the South Saskatchewan River, he reports having found in these buttes "stratified drift," and presents diagrams and a photograph of the river cutbanks (at the former Prelate Ferry), by which it appears that layers of this silty stratified drift and of stone-bearing till succeed one another for several cycles in this section. He says, "All the stratified drift units in the Prelate area were 
deposited mainly during the retreat of older ice sheets and during the readvance of the younger ice sheets. ${ }^{5}$ He does not seem to be curious why there is so much stratified drift along the river breaks but relatively little away from the river, as his boreholes testify. A suggested explanation is somewhat as follows: as the present river is in a large west to east preglacial river valley from Empress to Lancer Ferry, then every time the ice sheet advanced (as well as receded) a quantity of stratified drift would be deposited from eastflowing water in the valley. Lying in a topographic low at right angles to ice advance, not all this stratified drift would be incorporated into the till when next the ice sheet overrode the valley. This was repeated several times. And nowadays in the outcrops, as pointed out by David, the till is tougher and more resistant to erosion and hence forms ledges, while the proglacial silts tend to weather down over the surface of the cutbank. Thus, to the casual observer the butte appears to consist mainly of buff silt with the occasional prominent ledge of till.

Serpent Spurge is widely distributed through the central United States from central and southeastern Montana down to Texas. ${ }^{3,6,8}$ In Canada, Scoggan gives old reports (1881-1901) for extreme southwestern Ontario, adding "? extinct or ? introduced." ${ }^{\prime 4}$ It is not mentioned in lists by Argus of the rare plants of Ontario. ${ }^{1,2}$

The other novelty is Fluffweed (Filago arvensis L.), which I found in the valley of Caton Creek northwest of Ravenscrag in 1991. Collection data are: \#5040, 28 August 1991, dry sandy bare eroded slope at junction of side ravine with Caton Creek, L.S.D. 13 in 21-7-24 W. 3rd; \#5041,
28 August 1991, abundant at foot on north bank of side ravine, L.S.D. 16 in 20-7-24 W. 3rd. Number 5041 had flowered early in the season and when collected was mostly dead from crowding, while \#5040 was scattered uncrowded plants flowering all summer and still living and growing. I was not sure the two collections were the same plant till I got them home. In overall appearance, Fluffweed looks much like the Marsh Cudweeds (Gnaphalium), but is strict and erect rather than sprawling. As in the latter, white wooly hairs cover the leaves and the small rayless composite heads. For its range outside Saskatchewan one may quote Hitchcock: "A European weed, recently collected several times in s.e. B.C. and adj. Wash., Ida., and Mont.; becoming common on overgrazed ranges, and to be expected to spread." " And it is doing so.

Not quite a first report is Fetid Marigold (Dyssodia papposa (Vent.) Hitchc.), an annual composite which looks like the cultivated marigolds of genus Tagetes seen through the wrong end of a telescope - even the smell of the crushed leaves is similar. These leaves, however, are twice or thrice pinnatifid into fine divisions, instead of only once. This plant was found as \#5086, 27 August 1992, a weed on gravel shoulders of \#11 Highway 2.6 mi north of Bladworth, L.S.D. 15 in 14-28-2 W. 3rd. But it is not a first finding; according to Dr. G.F. Ledingham in a letter of 12 November 1990, Myron Kopec collected Dyssodia in 1990 on \#1 Highway 2 mi. west (of Regina). The plant, native of North America, has a wide distribution through the central U.S. south of Saskatchewan; Flora of the Great Plains says "s. Ont., w. N.Y. to MT and $A Z$, s. to central Mex." According to Scoggan the southern Ontario report was based on a 19th century report from Fort 
Erie as a railroad weed; he adds "evidently not established."14

Three other range extensions are worth noting here:

1) Downingia (Downingia laeta Greene), was collected as \#5019, 14 August 1991, in a field pothole (cultivated slough bottom), soil glacial lake clay, L.S.D. 16 in 16-30-14 W. 3rd, near Rosetown. I had reported this earlier from a field pothole south of Leader, along with a summary of earlier findings by Macoun. ${ }^{10}$ The trouble with these collections of rare plants from field potholes (low spots in tilled fields which chanced not to be seeded in spring because of wetness) is that the odds are against someone repeating the collection in some later year, at least in that particular slough. The field may be in summerfallow; or there may not have been enough snow for significant spring run-off, in which case the surface occupant will put it in crop. The only reason that there were sloughs in that area worth examining for mud annuals was the heavy rains of MayJune 1991 - for about two decades we haven't had enough snowfall in the farmed part of Saskatchewan for major spring run-off. One can see that these mud annuals would undergo rigorous natural selection making for lengthy seed viability.

2) Cushion Everlasting (Antennaria dimorpha (Nutt.) T. \& G.) was collected as \#5044, 18 May 1992, on low spots in dry sandy prairie on L.S.D. 4 in 14-32-6 W. 3rd. This location is east of Round Prairie cemetery which lies at the south end of the Moose Woods flats along Highway \#219. This plant is reported by Maher from Altawan and Climax to Val Marie; their map shows five dots, all on the High Plains south of the Cypress Hills. ${ }^{13}$ Thus this Round Prairie collection is 225 miles out of range, but the surface was not at all disturbed other than by grazing.

3) Dwarf Fleabane (Erigeron radicatus Hook.) is mentioned by Maher from Cypress Hills, Simmie, and Wood Mountain. ${ }^{13}$ The Simmie record is mine, the other two are Macoun's. Scoggan also cites a Macoun collection in 1895 from Old Wives Creek (now Wood River) which from Macoun's account of this trip must have been taken along Lynthorpe Creek - the terrain along modern Wood River exhbits none of the bedrock outcrops to which this plant is confined. ${ }^{12,14}$

This smallest of the fleabanes may be recognized by being essentially acaulescent with no stem leaf or only a small one; it is also glabrous or nearly so, thus being yellow-green in distinction to the related species Tufted Fleabane (E. caespitosus) which is ashy-pubescent, and Plains Fleabane ( $E$. pumilus) which is villous with long white hairs. All three species have white ligules, only rarely feebly pinkish.

There are three collections of $E$. radicatus to be reported: \#4775, 12 May 1988, on eroded sandy slope, lowest part of Whitemud formation, Pinto Butte near former Wideview $P$. O., L.S.D. 11 in 21-2-9 W. 3rd; \#4778, 26 May 1988, steep windy northwest slope of cobbly knoll, west of Ravenscrag in L.S.D. 12 in 20-624 W. 3rd; \#4854, 19 June 1989 on quartzite cobble flats and junipercovered wash slopes around Whitemud outcrops, southeast of Aquadell in L.S.D. 1 in 16-20-6 W. 3rd. Geologically \#4778 was growing where the bedrock was Cypress Hills formation, but \#4775 and \#4854 came from or just by outcrops of the Whitemud formation. I have sight 
records also of $E$. radicatus: 1) from L.S.D. 13 in 35-5-20 W. 3rd (on the Whitemud River plateau southeast of Eastend) on 23 May 1988; and 2) from SE 1/4 8-7-28 W. 3rd (valley of Adams Creek east of Fort Walsh) on 3 June 1988. Both populations were growing among the cobble-stones lapping over the edges of a Whitemud outcrop.

Duplicates of all numbered collections have been distributed to the herbaria of the University of Saskatchewan, the University of Regina, and the National Museum of Canada.

1. ARGUS, G.W., and D.J. WHITE. 1977. The rare vascular plants of Ontario. Syllogeus \#14, National Museums of Canada, Ottawa.

2. ARGUS, G.W. et al. Atlas of the rare vascular plants of Ontario. National Museum of Natural Sciences, Ottawa, 1982-1987.

3. Atlas of the flora of the Great Plains. 1977. lowa State Univ. Press, Ames.

4. BOOTH, W.E., and J.C. WRIGHT. 1966. Flora of Montana, Part II. Montana State Univ., Bozeman.

5. DAVID, P.P. 1964. Surficial geology and groundwater resources of the Prelate area (72K) Saskatchewan.
Ph.D. Thesis, McGill Univ., Montreal.

6. DORN, R.D. 1984. Vascular plants of Montana. Mountain West Publishing, Cheyenne, WY.

7. Flora of the Great Plains. 1986. Univ. Press of Kansas, Lawrence, KS.

8. FERNALD, M.L. 1950. Gray's manual of botany, (8th ed.) American Book, New York.

9. HITCHCOCK, C.S., et al. 1955. Vascular plants of the Pacific Northwest, Vol. 5. Univ. of Washington Press, Seattle, 1955. Vol. 5 is attributed to A. C. Cronquist alone.

10. HUDSON, J.H. 1980. Plant finds from Saskatchewan in 1978 and $1979-$ mostly from the southwest. Blue Jay 38:141-145.

11. - 1988. Foxtail Muhly new to Saskatchewan, Rigid Sedge reaffirmed, additional range extensions. Blue Jay 46:71-74.

12. MACOUN, J. 1985. Geological Survey of Canada annual report, new series, Vol. VIII, Report A, pp. 141A-148A.

13. MAHER, R.V., G.W. Argus, V.L. Harms, and J.H. Hudson. 1979. The rare vascular plants of Saskatchewan. Syllogeus \#20. National Museums of Canada, Ottawa.

14. SCOGGAN, H.J. 1979. The flora of Canada. National Museums of Canada, Ottawa.

Birders: An overlapping term with "bird watchers," who observe the birds' behaviour. "Birders" have a special interest in adding to their lists of species sighted. In Britain, they are known as "twitchers" - a term they dislike - and there are currently three paging services that rent beepers to alert them when a rare bird visits the British Isles. Bird-watching. The Globe and Mail, 8 March 1994. 